\title{
Model Pengembangan Kawasan Peternakan Sapi Aceh di Kabupaten Aceh Jaya Propinsi Aceh
}

\section{The Model of development the Aceh Cattle in Aceh Jaya District of Aceh Province}

\author{
I. Mirza* dan W. Rahayu \\ Balai Pengkajian teknologi Pertanian (BPTP) Aceh, Banda Aceh, 23125 \\ *E-mail: is_mi63@yahoo.com
}

(Diterima: 11 Agustus 2017; Disetujui: 28 September 2017)

\begin{abstract}
ABSTRAK
Plasma nutfah sapi Aceh perlu dilestarikan dan dikembangkan dengan pendampingan teknologi agar peningkatan potensi dan pemanfaatan dapat dilakukan secara baik dan berkelanjutan. Pendampingan terhadap peternak diperlukan dalam upaya melindungi potensi genetik ternak lokal ini dan dalam upaya mensukseskan program pemerintah dalam mencapai swasembada daging melalui ternak lokal. Sapi Aceh mempunyai daya tahan terhadap lingkungan yang buruk seperti krisis pakan, air, pakan berserat tinggi, penyakit parasit, temperatur panas dan sistem pemeliharaan ekstensif tradisional. Berdasarkan data tahun 2011 dari 14.714 ekor sapi potong yang dipelihara, 13.939 ekor diantaranya merupakan sapi Aceh $(94,73 \%)$ dan data tahun 2012, dari 17.355 ekor sapi potong, 16.587 ekor diantaranya merupakan sapi Aceh (95,57\%). Demikian juga dengan data populasi sapi potong tahun 2013 dari 13.084 ekor sapi potong, 11.776 ekor adalah sapi Aceh (90,00\%) dan data tahun 2014 dari 15.370 ekor sapi potong, 14.497 ekor adalah sapi Aceh $(94,32 \%)$. Hal ini menunjukkan bahwa populasi sapi Aceh mendominasi dari total populasi sapi potong yang ada di Kabupaten Aceh Jaya. Di kabupaten Aceh Jaya terutama di kecamatan Sampoiniet, Darul Hikmah dan Setia Bakti terdapat 1.349 Ha padang penggembalaan, luasnya padang penggembalaan ini merupakan potensi sumber pakan yang cukup untuk memenuhi kebutuhan pakan sapi dan pengembangan kawasan peternakan Sapi Aceh apabila di revitalisasi dan dimanfaatkan secara optimal.
\end{abstract}

Kata kunci: sapi Aceh, pendampingan, populasi, kawasan peternakan

\section{ABSTRACT}

The Aceh cattle is one of the local genetic resources needs to be conserved and developed with the technological assistance for the farmers. The technical assistance for the farmers is necessary in order to protect the genetic potential of this local livestock, and also in the effort to succeed the government program in achieving self-sufficiency of meat through local livestock. Cattle Aceh is able to adapt well to the environment that is not optimal such as limited sources of feed, water, fibrous feed, parasitic diseases, and hot weather. Data from 2011 shows that of 14714 cows, 13939 head are Aceh cattle (94.73\%), and data from 2012 shows that $95.57 \%$ of beef cattle that are farmed by farmers are Aceh cows. In 2013 and 2014, the percentage of Aceh cattle raised by farmers is $90.90 \%$ and $94.32 \%$. This data shows that Aceh's cattle population dominates the total population of beef cattle in Aceh Jaya district. In Aceh Jaya district, especially in Sampoiniet, Darul Hikmah and Setia Bakti sub-districts, there is 1349 ha of grazing areas. The extent of the grazing area is a potential source of adequate feed to meet the needs of cattle feed in the development program of cattle ranch areas in Aceh if revitalized and optimally utilized.

Keywords: Aceh cattle, assistance program, population, farming areas

\section{PENDAHULUAN}

Provinsi Aceh mempunyai asset plasma nutfah sapi Aceh yang telah sejak dahulu memegang peranan penting bagi masyarakat di pedesaan yang telah mengakar dalam kehidupan ekonomi, sosial dan budaya masyarakat Aceh. Keberadaan sapi Aceh sebagai salah satu rumpun sapi lokal Indonesia telah ditetapkan melalui Keputusan Menteri 
Pertanian Nomor: 2907/Kpts/OT.140/6/2011 tanggal 17 Juni 2011. Plasma nutfah sapi Aceh perlu dilestarikan agar peningkatan potensi dan pemanfaatan dapat dilakukan secara baik dan berkelanjutan. Dukungan diperlukan dalam upaya melindungi potensi genetik ternak lokal ini dan untuk mencegah terjadinya masalah di kemudian hari yang berkaitan dengan klaim terhadap sapi Aceh oleh negara-negara lain.

Dengan ditetapkan sapi Aceh sebagai salah satu rumpun sapi lokal di Indonesia, maka Pemerintah Pusat, Pemerintah Aceh dan Pemerintah Aceh Jaya telah melakukan upaya penetapan Pulo Raya sebagai kawasan pemurnian plasma nutfah sapi Aceh (Keputusan Bupati Aceh Jaya Nomor 25 tahun 2011).

Pulo Raya secara geografis berada pada kecamatan Sampoiniet. Pengembangan sapi Aceh sebagai komoditas peternakan adalah sarana untuk menyediakan bibit yang berkualitas dan diharapkan dapat berkelanjutan. Ada 2 kecamatan lain yang berdekatan dengan kecamatan Sampoiniet yaitu kecamatan Setia Bakti dan kecamatan Darul Hikmah. Ketiga kecamatan ini (Sampoiniet, Setia Bakti dan Darul Hikmah) mempunyai potensi yang cukup baik untuk pengembangan sapi Aceh dan berpeluang menjadi wilayah sumber bibit sapi Aceh.

\section{METODE}

Penelitian dilakukan di Kecamatan Sampoiniet, Darul Hikmah dan Setia Bakti, pada tahun 2015 -2016. Kegiatan yang dilakukan adalah pengambilan data primer dan data sekunder, diseminasi dan pendampingan teknologi pakan, manajemen pemeliharaan ternak, manajemen kesehatan ternak dan manajemen perkawinan ternak dalam peningkatan performa dan populasi Sapi Aceh dikawasan peternakan Kabupaten Aceh Jaya.

\section{HASIL DAN PEMBAHASAN}

\section{Sapi Aceh}

Hasil analisis molekuler menunjukkan bahwa, sapi Aceh berasal dari sapi India (Bos indicus) yang kemudian mengalami hibridisasi dengan Bos javanicus (domestikasinya sapi Bali) di Indonesia (Abdullah et al., 2008). Menurut Nozawa (1979), pusat penyebaran gen sapi Zebu (Bos indicus) yaitu dari India. Secara maternal (garis induk), sapi Aceh merupakan sapi turunan Bos indicus (Abdullah et al., 2008). Persamaan susunan basa nukleotida sapi Aceh dan Bos indicus adalah sebesar 94,36\% dan terhadap Bos taurus sebesar 88,52\%, sehingga sapi Aceh dekat dengan sapi Bos indicus. Hal ini membuktikan bahwa sapi Aceh adalah dari maternal Zebu. Penentuan daerah D-loop mtDNA pada sapi dapat menunjukkan sejarah sapi (Nijman et al., 2003; Edwards et al., 2007) dan hibridisasi yang terjadi pada Banteng dan sapi Madura (Nijman et al., 2003).

Sapi Aceh adalah tipe sapi potong berukuran kecil serta mempunyai kontribusi yang cukup besar bagi pemenuhan kebutuhan daging di daerah. Menurut Martojo (2003), sapi Aceh merupakan satu dari empat bangsa sapi asli (sapi lokal) Indonesia (Aceh, Pesisir, Madura dan Bali). Sapi Sumba-Ongole dan Java-Ongole (PO) juga dianggap sebagai bangsa sapi lokal Indonesia. Noor (2008) menyatakan bahwa, ternak-ternak asli telah terbukti dapat beradaptasi dengan lingkungan dan iklim tropik. Dengan demikian, ternakternak inilah yang paling cocok untuk dipelihara dan dikembangkan di Indonesia, walaupun produksinya lebih rendah dari ternak impor.

Menurut Gunawan (1998), sapi Aceh mempunyai daya tahan terhadap lingkungan yang buruk seperti krisis pakan, air dan pakan berserat tinggi, penyakit parasit, temperatur panas dan sistem pemeliharaan ekstensif tradisional.

Selain unggul atas daya reproduksi dan daya adaptasi pada lingkungan baru, sapi 
Tabel 1. Beberapa keunggulan sapi Aceh.

\begin{tabular}{clc}
\hline No. & Sifat & Penilaian \\
\hline 1 & Sifat Kuantitatif: & \\
& Kesuburan induk & $85-90 \%$ \\
& Angka kelahiran & $60-72 \%$ \\
& Persentase karkas & $52-55 \%$ \\
& Kadar lemak daging & $3-6 \%$ \\
& Kemampuan hidup hingga dewasa & $70-85 \%$ \\
\hline 2 & Sifat Kualitatif & \\
& Kemampuan kerja & Baik \\
& Kemampuan hidup secara liar & Baik \\
& Daya adaptasi terhadap pakan terbatas & Baik \\
& Daya adaptasi terhadap air minum payau/buruk & Baik \\
& Daya adaptasi terhadap tekanan panas & Baik \\
& Daya tahan terhadap serangan parasit & Baik \\
Kemampuan mencerna pakan dan serat kasar tinggi & Baik \\
\hline
\end{tabular}

Sumber: Manan (2011)

Tabel 2. Populasi Ternak Ruminansia di Kabupaten Aceh Jaya Tahun 2011 - 2014.

\begin{tabular}{clcccccc}
\hline \multirow{2}{*}{ No } & \multirow{2}{*}{ Jenis Ternak } & \multicolumn{7}{c}{ Tahun (ekor) } \\
\cline { 3 - 8 } & & 2011 & 2012 & 2013 & $2014^{*}$ & $2015^{* *}$ & $2016^{* * *}$ \\
\hline 1 & Sapi Potong & 14.714 & 17.355 & 13.084 & 15.370 & 15.522 & 15.965 \\
2 & Sapi Aceh & 13.939 & 16.587 & 11.776 & 14.497 & 13.970 & 14.596 \\
3 & Sapi Perah & - & - & - & - & - & - \\
4 & Kerbau & 2.589 & 3.226 & 2.387 & 3.475 & 3.510 & 3.684 \\
6 & Kambing & 21.906 & 33.129 & 34.784 & 36.290 & 36.652 & 38.466 \\
7 & Domba & 30.475 & 3.769 & 3.957 & 4.055 & 4.097 & 4.298 \\
\hline
\end{tabular}

Sumber: * Database Peternakan Kabupaten Aceh Jaya Tahun 2014

** Data Peternakan (Sementara) Kabupaten Aceh Jaya Triwulan I Tahun 2015

*** Data Peternakan (Estimasi) Kabupaten Aceh Jaya Tahun 2016

Aceh juga mempunyai keunggulan persentase karkas (Wahab et al., 1989). Selanjutnya Manan (1992) mengatakan bahwa, sapi Aceh tahan terhadap serangan caplak dan cacing serta serangan MCF (Malignant Catarrhal Fever). Secara umum keunggulan sapi Aceh tertera dalam Tabel 1.

\section{Populasi Ternak}

Pemerintah Aceh, Cq. Dinas Kesehatan Hewan dan Peternakan telah mendirikan BPTHMT Indrapuri pada: 28 Mei 1978 dengan SK No. 313/Kpts/ Ong/1978. Selanjutnya berubah menjadi Balai Pembibitan Ternak Unggul (BPTU)
Sapi Aceh Indrapuri NAD dengan SK Mentan No. 282/Kpts/T.210;4/2002, yang sekarang telah memiliki sapi Aceh sebanyak 415 ekor sebagai aset pemula pemurnian sapi Aceh.

Data perkembangan populasi ternak di Kabupaten Aceh Jaya tahun 2011 sampai 2014 dapat dilihat pada Tabel 2. Populasi ternak ruminansia besar yang terbanyak adalah populasi sapi potong. Berdasarkan data tahun 2011 dari 14.714 ekor sapi potong yang dipelihara, 13.939 ekor diantaranya merupakan sapi Aceh $(94,73 \%)$ dan data tahun 2012, dari 17.355 ekor sapi potong, 16.587 ekor diantaranya merupakan sapi Aceh $(95,57 \%)$. Demikian juga dengan data 
Tabel 1. Data Skala Pemeliharaan Ternak di Kecamatan Setia Bakti, Sampoiniet dan Darul Hikmah.

\begin{tabular}{clc}
\hline No & Skala Pemeliharaan Ternak & Jumlah (orang) \\
\hline 1 & $<3$ ekor & 168 \\
2 & $3-6$ ekor & 469 \\
3 & $7-9$ ekor & 374 \\
4 & $10-12$ ekor & 134 \\
5 & $13-15$ ekor & 98 \\
6 & $>15$ ekor & 67 \\
\hline & Jumlah & 1.310 \\
\hline
\end{tabular}

Sumber: BPP Kabupeten Aceh Jaya, 2014.

Tabel 4. Data Kepemilikan Ternak di Kecamatan Setia Bakti, Sampoiniet dan Darul Hikmah.

\begin{tabular}{clc}
\hline No & Kepemilikan Ternak & Jumlah (orang) \\
\hline 1 & Milik Sendiri & 1.131 \\
2 & Bagi Hasil & 179 \\
\hline & Jumlah & 1.310 \\
\hline
\end{tabular}

Sumber: BPP Kabupeten Aceh Jaya, 2014.

populasi sapi potong tahun 2013 dari 13.084 ekor sapi potong, 11.776 ekor adalah sapi Aceh $(90,00 \%)$ dan data tahun 2014 dari 15.370 ekor sapi potong, 14.497 ekor adalah sapi Aceh (94,32\%). Hal ini menunjukkan bahwa populasi sapi Aceh mendominasi dari total populasi sapi potong yang ada di Kabupaten Aceh Jaya. Artinya potensi pengembangan ternak khususnya sapi Aceh di Kabupaten Aceh Jaya cukup baik.

\section{Skala Pemeliharaan}

Ternak sapi yang dipelihara di Kabupaten Aceh Jaya umumnya sapi Aceh dengan rata-rata $93,66 \%$ (tahun 2011 2014) dari total populasi sapi potong. Ratarata penguasaan ternak sapi potong (skala pemeliharaan) adalah 4,34. Artinya setiap rumah tangga pemelihara memiliki sekitar 3 -5 ekor sapi.

Hasil Sensus Pertanian 2013 (ST2013) menunjukkan bahwa jenis unit pemelihara ternak khususnya sapi potong hampir seluruhnya didominasi oleh rumah tangga sebanyak 3.032 pemelihara sedangkan pedagang lainnya tercatat hanya 3 pemelihara.

Khusus untuk daerah wilayah sumber bibit, jumlah petani/peternak sebanyak 1.310 orang dengan skala pemeliharaan berkisar antara $2-15$ ekor. Data selengkapnya mengenai umur peternak, tingkat pendidikan, pengalaman beternak, kepemilikan ternak dan data skala pemeliharaan ternak, dapat dilihat pada Tabel 3 dan Tabel 4.

Petani/peternak di wilayah sumber bibit dari 1.310 orang petani/peternak di wilayah sumber bibit terdapat kepemilikan ternak milik sendiri sebanyak 1.131 orang dan sisanya bagi hasil sebanyak 179 orang (Tabel 4).

\section{Ketersediaan Pakan}

Dalam pemeliharaan ternak, pakan memegang peranan yang sangat penting karena hampir $70 \%$ biaya produksi adalah didominasi oleh pakan. Di kabupaten Aceh Jaya terutama di kecamatan Sampoiniet, Darul Hikmah dan Setia Bakti terdapat 1.349 Ha padang penggembalaan yang sebarannya dapat dilihat pada Tabel 5. Luasnya padang penggembalaan ini merupakan potensi sumber pakan yang cukup apabila padangan tersebut di revitalisasi dan dimanfaatkan secara optimal. 
Tabel 5. Padang Pengembalaan di Kecamatan Sampoiniet, Darul Hikmah dan Setia Bakti.

\begin{tabular}{|c|c|c|c|}
\hline No & Kecamatan & Desa & Luas (Ha) \\
\hline \multirow[t]{9}{*}{1} & Sampoiniet & Kuala Bakung & 80 \\
\hline & & Kuala Ligan & 25 \\
\hline & & Alue Groe & 100 \\
\hline & & Ie Jeureungeh & 25 \\
\hline & & Ranto Sabon & 35 \\
\hline & & Cot Punti & 40 \\
\hline & & Seumantok & 40 \\
\hline & & Pulo Raya & 50 \\
\hline & Jumlah & & 395 \\
\hline \multirow[t]{8}{*}{2} & Darul Hikmah & Patek & 4 \\
\hline & & Pajar & 10 \\
\hline & & Masen & 20 \\
\hline & & Krueng Tho & 20 \\
\hline & & Ujong Rimba & 15 \\
\hline & & Gunong Cut & 30 \\
\hline & & Cot Langsa & 35 \\
\hline & Jumlah & & 134 \\
\hline \multirow[t]{12}{*}{3} & Setia Bakti & Lhok Bot & 22 \\
\hline & & Lhok Timon & 15 \\
\hline & & Lhok Geulumpang & 18 \\
\hline & & Sawang & 10 \\
\hline & & Padang & 600 \\
\hline & & G. Meunasah & 15 \\
\hline & & Paya Laot & 40 \\
\hline & & Sapek & 30 \\
\hline & & Pante Kuyun & 50 \\
\hline & & Gp. Baroh & 20 \\
\hline & Jumlah & & 820 \\
\hline & Total & & 1.349 \\
\hline
\end{tabular}

Sumber: Dinas Pertanian dan Peternakan Kabupaten Aceh Jaya, 2014.

Di Kabupaten Aceh Jaya terdapat lahan pertanian seperti lahan sawah padi dan lahan tanaman jagung. Limbah pertanian tanaman ini dapat digunakan untuk mengatasi kekurangan pakan pada musim kemarau dengan menerapkan teknologi fermentasi (jerami padi dan jagung). Luas lahan tanaman sawah padi dan tanaman jagung di wilayah sumber bibit adalah $2.744 \mathrm{Ha}$ dan $46 \mathrm{Ha}$ (Tabel 6). Berbagai Jenis Tanaman Pakan yang terdapat pada di Kecamatan Sampoiniet, Darul Hikmah dan Setia Bakti (Tabel 7, 8 dan 9).

\section{Manajemen Pakan}

Pengelolaan pakan akan sangat menentukan tingkat keberhasilan pemeliharaan sapi. Oleh karena itu, cara-cara pengelolaannya harus dipahami.

Ketersediaan padang penggembalaan pada pemeliharaan ternak sapi diperlukan sekali sebagai sumber pakan hijauan. Pemberian pakannya dapat dilakukan dengan pemotongan rumput tersebut, kemudian diberikan pada ternak sapi yang ada di dalam kandang. Pemberian pakan seperti 
Tabel 6. Estimasi daya dukung limbah tanaman Tanaman Padi dan Jagung di Kecamatan Sampoiniet, Darul Hikmah dan Setia Bakti.

\begin{tabular}{lcccc}
\hline Jenis tanaman & $\begin{array}{c}\text { Luas } \\
(\mathrm{Ha})\end{array}$ & $\begin{array}{c}\text { Produksi/ } \\
\text { tahun (Ton) }\end{array}$ & $\begin{array}{c}\text { Produksi Limbah/ } \\
\text { tahun (Ton) }\end{array}$ & $\begin{array}{c}\text { Estimasi daya dukung } \\
\text { (ekor) }\end{array}$ \\
\hline Padi & 2.744 & 9.392 & 17,0 & 850 \\
Jagung & 46 & 75 & 2,5 & 100 \\
\hline
\end{tabular}

Sumber: BPP Kabupaten Aceh Jaya, 2014.

Tabel 7. Berbagai Jenis Tanaman Pakan di Kecamatan Setia Bakti.

\begin{tabular}{lcccc}
\hline $\begin{array}{l}\text { Jenis tanaman sebagai } \\
\text { bahan pakan }\end{array}$ & $\begin{array}{c}\text { Luas } \\
\text { (ha) }\end{array}$ & $\begin{array}{c}\text { Produksi/ } \\
\text { tahun (ton) }\end{array}$ & $\begin{array}{c}\text { Produksi Limbah/ } \\
\text { tahun (ton) }\end{array}$ & $\begin{array}{c}\text { Ternak yang dapat } \\
\text { mengkonsumsi (ekor) }\end{array}$ \\
\hline Rumput Alam & 639 & 6400 & 1700 & 1906 \\
Rumput Gajah & 40 & 2000 & 500 & 1500 \\
Rumput BH & 35 & 3500 & 1000 & 2500 \\
Tanaman Pisang & 100 & 5000 & 2000 & 3000 \\
Limbah Tanaman Sawit & 465 & 1674 & 1200 & 474 \\
Limbah Tanaman Coklat & 98 & 79 & 15 & 64 \\
\hline
\end{tabular}

Sumber: Dinas Pertanian dan Peternakan Kabupaten Aceh Jaya, 2014.

Tabel 8. Berbagai Jenis Tanaman Pakan di Kecamatan Sampoiniet.

\begin{tabular}{lcccc}
\hline $\begin{array}{l}\text { Nama tanaman/tumbuhan } \\
\text { sebagai bahan pakan }\end{array}$ & $\begin{array}{c}\text { Luas } \\
\text { (ha) }\end{array}$ & $\begin{array}{c}\text { Produksi/ } \\
\text { tahun (ton) }\end{array}$ & $\begin{array}{c}\text { Produksi Limbah/ } \\
\text { tahun (ton) }\end{array}$ & $\begin{array}{c}\text { Ternak yang dapat } \\
\text { mengkonsumsi (ekor) }\end{array}$ \\
\hline Rumput Alam & 380 & 2151 & 69 & 2082 \\
Rumput Gajah & 101 & 1293 & 553 & 740 \\
Rumput BH & 53 & 67 & 32 & 35 \\
Tanaman Pisang & 121 & 5521 & 2123 & 2398 \\
Limbah Tanaman Sawit & 513 & 2176 & 437 & 1739 \\
Limbah Tanaman Coklat & 71 & 63 & 14 & 49 \\
\hline
\end{tabular}

Sumber: Dinas Pertanian dan Peternakan Kabupaten Aceh Jaya, 2014.

Tabel 9. Berbagai Jenis Tanaman Pakan di Kecamatan Darul Hikmah.

\begin{tabular}{lcccc}
\hline $\begin{array}{l}\text { Nama tanaman/tumbuhan } \\
\text { sebagai bahan pakan }\end{array}$ & $\begin{array}{c}\text { Luas } \\
\text { (ha) }\end{array}$ & $\begin{array}{c}\text { Produksi/ } \\
\text { tahun (ton) }\end{array}$ & $\begin{array}{c}\text { Produksi Limbah/ } \\
\text { tahun (ton) }\end{array}$ & $\begin{array}{c}\text { Ternak yang dapat } \\
\text { mengkonsumsi (ekor) }\end{array}$ \\
\hline Rumput Alam & 105 & 1971 & 79 & 1892 \\
Rumput Gajah & 15 & 728 & 253 & 475 \\
Rumput BH & 5 & 14 & 7 & 7 \\
Tanaman Pisang & 212 & 4532 & 2342 & 2190 \\
Limbah Tanaman Sawit & 475 & 1321 & 527 & 794 \\
Limbah Tanaman kakao & 51 & 43 & 14 & 28 \\
\hline
\end{tabular}

Sumber: Dinas Pertanian dan Peternakan Kabupaten Aceh Jaya, 2014.

ini disebut cut and carry. Selain itu, rumput juga dapat dikonsumsi langsung oleh sapi di areal padang penggembalaan berdasarkan pada stocking rate (daya tampung) padang penggembalaan tersebut untuk mencukupi kebutuhan penggembalaan setiap UT (Unit Ternak) (Santosa, 2005). Ketersediaan pakan harus mencukupi kebutuhan ternak, baik yang berasal dari hijauan/rumput, maupun pakan konsentrat yang dibuat sendiri atau berasal 


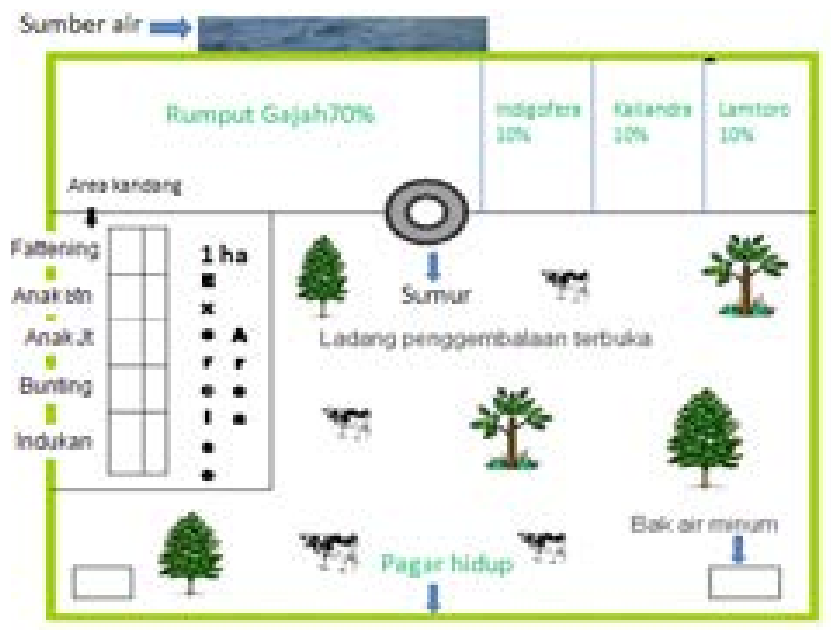

Gambar 1. Desain model padang penggembalaan sapi

dari pabrik (Direktorat Jenderal Peternakan, 2000).

Di Kabupaten Aceh Jaya terutama di kecamatan Sampoiniet, Darul Hikmah dan Setia Bakti terdapat 1.349 Ha padang penggembalaan. Perbaikan terhadap Kondisi eksisting dikawasan pengembangan peternakan sapi potong adalah dengan menanam rumput Brachaeria Humidicola (BH) sebagai rumput lapangan atau rumput gembala. Produksi Bahan Kering rumput BH rata-rata $30 \mathrm{ton} / \mathrm{ha} /$ tahun. $1 \mathrm{Ha}$ lahan dapat menampung 4 ekor ternak, maka dengan luas padang penggembalaan $1.349 \mathrm{Ha}$ dapat menampung 337 ekor sapi. Itu artinya jika hanya dengan lahan penggembalaan saja tidak mampu menampung seluruh jumlah ternak yang ada di kabupaten aceh jaya, untuk memenuhi kebutuhan hijauan pakan ternak dilakukan penanaman rumput gajah mini seluas 4 Ha sebagai percontohan. Rumput gajah mini mampu ber produksi hingga 60 ton per tahun. Selain itu juga dilakukan penanaman indigofera seluas $2 \mathrm{Ha}$ sebagai leguminosa sumber protein, dan pemanfaatan limbah pertanian sebagai pakan ternak.

Rumput potong diberikan sebagai tambahan pada malam hari setelah ternak dilepaskan dipadang penggembalaan. Kemudian untuk memenuhi protein diberikan indigofera, sedangkan sebagai sumber mineral, peternak dilatih cara pembuatan Urea
Mineral Blok.

\section{Manajemen Pemeliharaan}

Dengan manajemen perkandangan yang sudah diperbaiki maka manajemen pemeliharaan juga diatur dengan baik. Pada pagi hari hingga sore hari ternak dilepas ke padang pemnggembalaan dengan makan rumput alam dan rumput lapangan yang ada di padang penggembalaan secara adlibitum, kemudian pada sore hari ternak kembali kekandang, diberikan pakan rumput potong (rumput gajah mini) dan leguminosa indogofera $10 \%$ dari berat badan ternak untuk pemenuhan protein dan TDN sesuai dengan kebutuhan ternak (Sugeng, 2005). Desain model padang penggembalaan Sapi Aceh di Kabupaten Aceh Jaya dapat dilihat pada Gambar 1.

\section{Manajemen Perkawinan}

Sapi dapat dikembangbiakan dengan dua metode yang umum dikenal, yaitu:

1. Metode alamiah yaitu sapi jantan pemacek dikawinkan dengan sapi betina yang sedang birahi, sperma sapi jantan pemacek untuk perkawinan alamiah hanya mampu melayani 120 ekor sapi betina/tahun,

2. Metode inseminasi buatan (IB), metode ini lebih populer dikenal dengan kawin suntik. Perkawinan dilakukan dengan bantuan peralatan khusus dan manusia (inseminator), seekor sapi jantan pemacek 
sebagai sumber sperma dapat dipergunakan untuk mengawini sapi betina sampai 20.000 ekor/tahun (Hernowo, 2006).

Selama ini sistem perkawinan ternak merupakan sistem perkawinan alami yang tidak terkontrol dengan perbandingan pejantan dan betina 1:25 sehingga tingkat in breeding sangat tinggi, anak yang dilahirkan semakin kecil dan kerdil. Untuk itu dilakukan pendampingan tentang manajemen perkawinan ternak, yaitu dengan memberikan mataeri pelatihan mengenai gejala birahi ternak betina, waktu perkawinan yang tepat dan ciri-ciri pejantan yang baik. Rotasi pejantan unggul sangat penting dilakukan untuk menghindari in breeding mendapatkan pedet yang sehat dan unggul.

\section{Angka Kelahiran dan Kematian Pedet Sapi Aceh}

Perkembangan populasi sapi Aceh di daerah Kabupaten Aceh Jaya pada tahun 2014 sebesar 3,09\% dan pada tahun 2015 sebesar $5,24 \%$. Hal ini berkaitan dengan angka kelahiran sapi yaitu $72 \%$ pertahun dan adanya kematian pedet $\pm 15 \%$. Angka kelahiran Pedet sapi Aceh rata-rata kelahiran pedet: $72 \%$ dengan kisaran $65-80 \%$ dari angka kebuntingan $80 \%$. Kematian pedet sebenarnya amat rendah, apabila kelahiran tersebut terjadi pada awal musim kemarau atau pada saat hujan ringan bulan Mei. Kematian pedet biasanya karena kelahiran terjadi saat musim hujan berat yaitu Desember dan Januari. Kematian pedet biasanya terjadi karena kekurangan air susu induk, akibat diare dan penyakit saluran pernapasan. Disamping itu, kematian pedet juga terjadi akibat serangan cacing (Neoascaris).

\section{Manajemen Kesehatan Ternak}

\footnotetext{
Manajemen pemeliharaan yang dipraktekkan oleh petani dengan cara menggembalakan di padang penggembalaan sangat rawan terhadap serangan parasit cacing nematoda maupun trematoda. Salah satu penanggulangan nya adalah pemberian obat cacing secara reguler. Pemberian obat cacing harus diberikan secara rasional.
}

diperlukan rotasi penggunaan obat cacing dari satu golongan tertentu kepada golongan lainnya. Misalnya pada tahun ini digunakan obat cacing dari golongan benzimidazole, tahun berikutnya sebaiknya digunakan dari golongan levamisole.

Pemberian obat cacing dilaksanakan berdasarkan hasil analisa feses di laboratorium. Metoda analisis feses yang digunakan adalah metoda McMaster. Pemeriksaan ini bertujuan untuk melihat tingkat infestasi cacing dengan melihat jumlah telur cacing nematoda per gram tinja (ttgt) atau egg per gram (EPG) dan efektivitas dari obat cacing yang digunakan.

\section{KESIMPULAN}

Kawasan peternakan sapi Aceh merupakan Aset yang sangat besar yang perlu dikembangkan dan diberi pendampingan agar tetap terjaga dan berkembang, sehingga dapat membantu memenuhi kebutuhan daging baik di propinsi maupun secara nasional. Hal yang sangat penting dalam pengembangan kawasan peternakan sapi aceh adalah Pendampingan teknologi pakan ternak, manajemen pemeliharaan, manajemen perkawinan dan manajemen kesehatan.

\section{DAFTAR PUSTAKA}

Abdullah, M. A. N., R. R. Noor dan E. Handiwirawan. 2008. Identifikasi penanda genetik daerah D-loop pada sapi Aceh. J.Indon.Trop.Anim.Agric. 33 (1):1-10.

Abdullah, M. A. N., R. R. Noor dan Iqbar. 2009. Identifikasi Genetik Spesifik pada Sapi Aceh dengan Menggunakan Marker D-loop DNA Sitoplasma. Laporan Penelitian. Lembaga Penelitian Unsyiah, Banda Aceh.

BPTU Sapi Aceh. 2011.

Gunawan. 1998. Upaya Peningkatan Mutu Genetik Sapi Aceh. Pidato Pengukuhan dalam Jabatan Guru Besar Tetap Fakultas Pertanian Universitas Syiah 
Kuala. Disampaikan pada Rapat Senat Terbuka Universitas Syiah Kuala, Sabtu 28 Maret 1998, Banda Aceh.

Hernowo, B. 2006. Prospek pengembangan usaha peternakan sapi potong di Kecamatan Surade Kabupaten Sukabumi. Skripsi. Program Studi Sosial Ekonomi Peternakan. Fakultas Peternakan. Institut Pertanian Bogor, Bogor.

Martojo, H. 2003. Indigenous Bali Cattle: The Best Suited Cattle Breed for Sustainable Small Farms in Indonesia. Laboratory of Animal Breeding and Genetics, Faculty of Animal Science, Bogor Agricultural University, Indonesia.

Nijman, I. J., M. Otsen, E. L. C. Verkaar, C. D. Ruijter, E. Hanekamp, J. W. Ochieng, S. Shamshad, J. E. O. Rege, O. Hanotte, M. W. Barwegen, T. Sulawati and J. A. Lenstra. 2003. Hybridization of banteng (Bos javanicus) and zebu (Bos indicus) revealed by mitochondrial DNA, satellite DNA,
AFLP and microsatellites. Heredity. 90: $10-16$.

Noor, R. R. 2008. Genetika Ternak. Cet ke-5. Penebar Swadaya, Jakarta.

Nozawa, K. 1979. Phylogenetics studies on the native domestic animals in East and Southeast Asia. Proc. Workshop Animals Genetics Resources in Asia and Oceania. Tsakuba, 3-7 September 1979. Tsukuba: Society for the Advancement of Breeding Researches in Asia and Oceania (SABRAO) 2343.

Santosa, U. 2005. Tata Laksana Pemeliharaan Ternak Sapi. Penebar Swadaya. Jakarta.

Sugeng, Y. B. 2005. Sapi Potong. Penebar Swadaya, Jakarta.

Wahab, A. A., Syafruddin dan Zunnizam. 1989. Pengamatan pertambahan berat badan Sapi Aceh jantan pada Perusahaan sapi potong dan perah PT. AAD di Blang Rakal. 